\title{
Влатко Деловски
}

vlatkodelovski@gmail.com

\section{Фолтин и Клод , леви-скроз”}

\section{(Исчитување на поезијата во музиката на ,Фолтин"1)}

\begin{abstract}
. Деловски Влатко, Фолтин и Клод „леви-скроз” (Исчитување на поезијата во музиката на „Фолтин") (Foltin and Claude "levi-skroz" [Poetry readings of the music of "Foltin”]). „Poznańskie Studia Slawistyczne” 2. Poznań 2012. Adam Mickiewicz University Press, pp. 95-117. ISBN 978-83-232-2409-9. ISSN 2084-3011.

Foltin is a musical community, and I say community and not group, because the word group is associated with the crowd. This is my attempt to try to explain the process of reading the important characteristics of purposeful meaning in the poetry of Branko Nikolov (Foltin). This kind of reading is qualitatively different from ordinary reading. Namely, we will dare to read from an ethnographic point of view, which means investigating, i.e. analyzing with active participation. From the end of the 1990s until today, I have attended all significant "Foltin" events, which for me is something private, and therefore something that engages me is our common Vezilka, their poetry. Hence, reading is a job for our Vezilka - Lenka or as they prefer to say, the song 120 , while simple reading is a matter of my ignorance. From the surface level of their explicit manifestation (Music and Poetry), everything leads to a tangled, implicit poetic level. That is the process that we technically name reading, and reading looks like the one term that can be clearly marked as decoding from surface to deep structures.
\end{abstract}

Keywords: poetics, semiotics, structuralism, Claude Lévi-Strauss, Vezilka, Lenka, Foltin

${ }^{1}$ Cf. <www.facebook.com/foltin.band?sk=info> [преземено: 23.01.2012.]; <www. myspace.com/foltin> [преземено 27.01.2012.]; 〈www.youtube.com/jovanoski> [преземено: 27.01.2012]. 


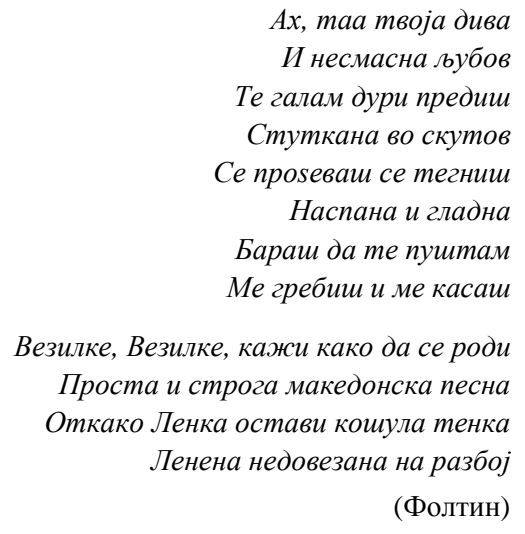

Уште како дете копнеев да станам композитор. Ми се чини дека само музиката и математиката се вродени, само за нив се потребни генетски предиспозиции. Се сеќавам дека за време на мојот престој во Њујорк, на една вечера, го прашав големиот француски композитор Дариус Мијо: „Кога сфативте дека ќе станете композитор?”. Тој ми објасни дека, уште како дете, додека заспивал, слушал некаква музика, која немала никаква врска со музиката која му била позната. Подоцна сфатил оти тоа била неговата музика²

\section{Музика во прозата?}

Обично станува збор за три камен - темелници на структурализмот: Сосир, Јакобсон и Клод Леви-Строс. Структурализмот, меѓу другото, од корен го измени и проучувањето и толкувањето на поезијата. Клучна за тоа беше 1962 година, кога Роман Јакобсон и Клод Леви-Строс ја објавија анализата на Бодлеровата песна Мачки, која набргу стана класика во високата структуралистичка пракса. Според Леви-Строс митот истовремено е дијахрониски (како историско раскажување на минатото) и синхрониски (како средство за објаснување на сегашноста, па дури и на иднината). Додека, пак, митемите претставуваат споеви на односите на тие два пристапа - дијахронискиот и синхронискиот. Новината на тоа време е во синхро-

\footnotetext{
${ }^{2}$ K. Levi-Stros, Mit i značenje, prev. Z. Minderović, Beograd 2009, str. 58-59.
} 
нискиот пристап на Леви-Строс кон митовите. Аналогно на Јакобсон, кој во фонемите виде помали, натаму неделиви единици - феми, Леви-Строс го подели митот на митеми - најмали, неделиви, а универзални единици на приказната. Митовите се еден вид јазик: тие можат да се сведат на базични индивидуални единици (митеми), кои како и основните гласовни единици на јазикот (фонемите) стекнуваат значење само кога се комбинираат според определени начини. Правилата кои раководат со таквите комбинации можат да се сметаат за еден вид граматика, систем од односи под површината на раскажувањето, каде се создава вистинското значење на митот. Леви-Строс смета дека овие односи се иманентни на човековата свест, така што кога го проучуваме „телото” на митот ние помалку гледаме во неговата расказна содржина, а повеќе во универзалните ментални операции кои го структурираат митот. Овие ментални операции создаваат бинарни опозиции (природа - култура; живот - смрт; добро - зло; светло - темно; свое - туѓо; свето - профано; суво - влажно; топло - ладно); тие се инструменти со чија помош мислиме; тие се начини за класификација и организација на реалноста, и токму тоа, а не раскажување на приказни, е смислата на митотвите ${ }^{3}$.

Леви-Строс на формално ниво ги споредува јазикот и музиката. Во јазкот основни елементи се фонемите - „апстрактен запис на звуци", кои ние непрецизно ги претставуваме со букви. Важно е што фонемите сами по себе не носат значење, туку во одредени комбинации. Истото може да се рече за музичките ноти. Впрочем, кај јазикот имаме фонеми, а во музиката имаме тонеми, како базични елементи. Комбинацијата на фонемите во јазикот формира зборови, потем комбинацијата на зборови формира реченици. Меѓутоа во музиката нема зборови, бидејќи комбинацијата на нотите директно формира фрази (музички реченици). Всушност, кај јазикот постојат три јасно одредени нивоа (фонеми, зборови, реченици), а во музиката, пак, нотите, кои одговараат на фонемите во јазикот, формираат музички дискурс кој одговара на нивото на реченици. Со други зборови, недостасува едно ниво кај музиката (тонеми, реченици), одно-

${ }^{3}$ Т. Иглтон, Структурализмот и семиотиката, во: Судбината на значењето, приред. В. Андоновски, Скопје 2007, стр. 45; K. Levi-Stros, op. cit., str. 58; E.M. Mелетински, Поетиката на митот, Скопје 2002, стр. 95-96, 107. 
сно е прескокнато, нема зборови. Кога ги споредуваме митот и јазикот, ја воочува следнава разлика: во митологијата нема фонеми; зборовите се најниското ниво. А ако го дефинираме јазикот како образец кој го формираат фонемите, зборовите и речениците, тогаш тој е парадигма и за митот и за музиката. Зашто во музиката нема еквивалент - зборови, но имаме еквивалент - фонеми и реченици. Во митот нема еквивалент на ниво на фонеми, но има еквивалент зборови и реченици. Како што веќе кажавме, во митот и во музиката недостасува едно ниво на формална сличност. Всушност, според Строс јазикот е појдовна точка за определување и на митот и на музиката. Впрочем, музиката и митот потекнуваат од јазикот, само што кај музиката преовладува звучниот аспект (кој е дел од јазикот), а кај митот преовладува значењето (кое, исто така, е дел од јазикот) ${ }^{4}$.

Леви-Строс ја наставува традицијата на интересот за музиката започната од времето на енциклопедизмот, односно француската теоретска мисла за музиката, во трудовите на Русо, Дидро, Рамо. Токму ова, но и неговото лично искуство е пресудно за неговата мисла кон музиката, нејзината длабока, животна, егзистенцијална, битна, тотална и космичка опчинетост. Не треба да се заборави дека Леви-Строс е рационалист и материјалист, но на музиката ứ „симнува капа”, за неа зборува со страхопочит, својствена за натприродно битие. На пример, од каде ни доаѓ такво чувство за бесмртност кога слушаме музика? - се прашува Леви-Строс. Густав Рис во воведот на своето дело за историјата на ренесансната музика сонува за „полифонија во прозата". И навистина, тоа не е возможно во прозата, чија суштина е формално линеарна и монофона, но тоа е она што структурализмот сакаше да биде, ама најчесто не успеваше: спој на фантазијата и логичкото 5 .

\section{Ленка и Конески}

Овде ќе стане збор за обидот направен од страна на Конески, за стилистичката анализа на песната Ленка од Кочо Рацин. Во песната Ленка Блаже Конески разликува два слоја. Едниот ја продолжува

\footnotetext{
${ }^{4}$ Cf. K. Levi-Stros, op. cit., str. 49-59.

${ }^{5}$ Cf. ibidem, str. 68-71.
} 
народната основа, а другиот врши актуелизација. Во народната традиција такво нешто е сосема нормална појава, но постапката кај Рацин е многу посложена.

Мотивот на Ленка е навеан од две популарни македонски народни песни За Марика и Билјана. Тука може да се заклучи дека првиот слој, во кој се продолжува народната основа, се пројавува јасно во двете средни строфи на Ленка, иако преку одделни елементи доаѓ до израз во сите делови на текстот. Улогата на овој слој е да го олесни непосредното емоционално дејство на песната. Самото тоа што кај читателите се будат познатите звуци на песните, што тие многупати ги слушнале, придонесува да се раздвижи еден цел комплекс на асоцијации и со тоа да се пренесе поефикасно емоционалниот набој на Рациновиот текст ${ }^{6}$.

За вториот слој во песната Ленка, Конески ќе напише:

Чинот на актуелизација се врши веќе со самото тоа што лирскиот јунак Ленка не е само девојка од народот, исполнета со трепетите и надежите на млада душа, ами е работничка, поставена во несносни животни услови. Тука се јавува спротивност меѓу лирскиот копнеж, пренесен со соодветна интонација, од една страна, а од друга, пак, грубата и сурова реалност. Во самиот почеток на песната доаѓ до израз и позицијата на социјално ангажиран поет, каков што беше Рацин. Како на пример: (...) карактеристични лексеми и изрази (монопол, тутун) (...) Не треба да го превидиме и излегувањето од рамките на двостихот, што не е никакво обично во народната поезија, а што остава скоро впечаток на прозаичност ${ }^{7}$.

Слободно може да се каже дека ова важи за Фолтин, само што Фолтин, во заклучокот на Блаже Конески за Рацин, го надвезуваат самиот Конески, вклучувајќи ја неговата Везилка во процесот на интеграција на нивната поезија. Прозаичниот карактер на првата строфа во песната на Фолтин е олицетворение на желбата на поетот за утринско зачнување, актуелизација на слободното утро. Растргнат меѓу елегијата (односно болката од љубовта и надежта) и експресионистичкиот поттик за нов поредок, Рацин целата последна строфа на песната Ленка ја поставува во контраст спрема почетокот на песната. Се чини дека Бранко - Фолтин тоа умешно го превртува во песната

\footnotetext{
${ }^{6}$ Б. Конески, За Кочо Ращин, Скопје 1994, стр. 73-74.

${ }^{7}$ Ibidem, cтp. 74-75.
} 
120. Имено, во оваа своја творба, втората прашална строфа упатена до Везилка (која користи и стих од првата строфа на песната Ленка), тој ја контрастира спрема неговото непосредното чувство, ја „растргнува зората" и го реактуелизира експресионистичкиот поттик за нова творба, над онаа што е претходно оставена („Везилке, Везилке кажи како да се роди?... откако Ленка... остави...”, песната 120 , дадена на почетокот).

Понатаму, на прашањето дали неговите песни комуницираат со публиката, затоа што се стремат кон поетичкиот идеал од стихот, „проста и строга македонска песна”, Конески одговара:

Тој израз „проста и строга македонска песна” го обврзува авторот и во смисла на откривање можноста за комуникација со публиката, тој, меѓу другото, содржи и вакво значење: песната треба да биде доведена до проsирен израз и да кажува нешто многу сериозно. А јас мислам дека публиката токму такви поетски текстови и прифаќа. Оние што носат некоја важна порака и оние во кои таа порака нашла свој проsирен, јасен израз ${ }^{8}$.

Авторот (Фолтин) успешно ја „дарува” промирноста на песната и нема потреба да ứ ce „додворува” на публиката. Зашто самата публика на концертите на Фолтин непосредно го објаснува овој јасен израз. Всушност Фолтин и публиката функционираат како пријателски комшиски дворови. Се работи за лесно прифатената структурална врска Везилка - Ленка, сервирана со препознатлив прибор (сите знаеме за Ленка и Везилка) и со суштински потребната комуникација на нивната музика со публиката (преполни сали, каде и да се појават), што според мое мислење, денес има супстанцијално значење. Во песната 120 на Фолтин, пред сѐ, се зама предвид значењето што меѓусебно го развиваат Везилка и Ленка (не значењето што го имаат сами по себе), како парадигма за актуелизација на поезијата, што ни е оставена на сите во наследство. Фолтин говори за континуитетот и врши актуелизација на идентитетот, бидејќи потсетува на нешто подзаборавено, дувнува во прашината и потребното го враќа на свое место. Затоа Фолтин ги фаворизираме како македонска група, а не затоа што се од Македонија (нивното творештво е универзално и се обраќа кон човекот).

\footnotetext{
${ }^{8}$ С. Мицковиќ, Поетските идеи на Конески, Скопје 1986, стр. 107.
} 
Во книгата Разговори со Конески ${ }^{9}$ можеме да го проследиме следново:

- Андреевски: Но вие не сте само пренесувач, само забележувач, на митовите. Вие изразувате еден цел спектар многу важни пораки и егзистенцијални суштини, валидни и за нашето време.

- Конески: Јас тоа и сум го објаснил во оној есеј Еден опит - што значи иновација на тие стари мотиви. Зашто јас лично сум тргнал од нашите традиции во смисла на конкретно пренесување на митските содржини. А не во смисла на тоа дека се тие содржини кај нас пронајдени. (...) Она што јас го актуелизирам, тоа се оние древни, најстари митови, што во различни историски манифестации дошле кај нас. А ние, пак, со нова лушпа ги обвиваме, за да ги искажеме со свој јазик своите размислувања, дилеми, тегоби. (...) Да, тие повремено и се актуализираат. И порано. И пред нас (..) За разлика од она што е во нашата народна традиција и во нашата народна песна, на Марко јас му давам димензија на интелектуален тип. Тоа е една прилична разлика, не? Но во секој случај останува тоа дека е тој на светлата страна (...) и визави на таа светла страна стои страната на злото. Кај мене не ја застапува таа страна некоја конкретна личност. Јас само велам - лошотијата, злото ${ }^{10}$.

Митското мислење се служи со средства што се „при рака”, кои можат да ја играат улогата и на материјал и на орудие, а елементите коишто имаат поголемо симболичко значење, чијшто корисник е веќе воспоставен мит, митската мисла може повторно да ги пушти во опсег. Во тој случај доаѓa до преуредување, разместување, како во калеидоскоп. Митската логика ги постигнува своите цели речиси ненамерно, по заобиколен пат, со игра на отскокнување - бриколаж ${ }^{11}$ ( bricolage од глаголот bricoler - 'да се игра со отскок, со рикошет' кој се применува во билјардот, во ловот, при јавање и др. $)^{12}$ и креација од различни материјали кои се „при рака”, материјали кои не се по-

\footnotetext{
${ }^{9}$ Ц. Андреевски, Разговори со Конески, Скопје 1991.

${ }^{10}$ Ibidem, стр. 303-305.

${ }^{11}$ Терминот ‘бриколаж’ доаѓ од францускиот збор bricolage, а се употребува во повеќе дисциплини: во визуелните уметности, музиката, литературата и сл. и означува креација од различни материјали кои се при рака, без оглед на нивната основна намена

${ }^{12}$ Е.М. Мелетински, ор. cit., стр. 98.
} 
себно наменети за таа цел. Митската мисла е како „домашен мајстор” кој може да направи различни работи без да ги има неопходните алатки, а згора на тоа и се служи со делови собирани по принципот „може да послужи" ${ }^{\text {„13 }}$.

Станува збор за универзалната граматика на човековата мисла, преку бинарни опозиции добро/зло, живот/смрт, светлина/темно и други. Начелно, овие бинарни опозиции, според структуралната врска што ја градат, се емпирија за човековата мисла и онтолошки се поврзани со човекот, а притоа ни даваат и една чудотворна специфика. Имено, чувство дека сите ние сме различни, посебни и современи (во извесна смисла на значењето, популарни). Тоа е така затоа што сите си играме со бројни, но вредносно исти играчки, со кои сепак правиме различни приказни. Различно ни се викаат јунаците, едни се високи и слаби, други дебели со бради, кодот на сите им е ист - сите се „љубители” на доброто/злото, животот/смртта. Ако Рацин е - глина и збор, Блаже Конески е - глина, ќерпич и збор. Фолтин е - глина, ќерпич, плет и збор. Тоа се бројни, но не и вредносни суштински разлики. Впрочем, вредносно најголемиот и универзален заеднички содржател на сите им е - зборот. Во прилог на последново ке кажеме дека Леви-Строс размислува: „ако јазикот некогаш бил ро-

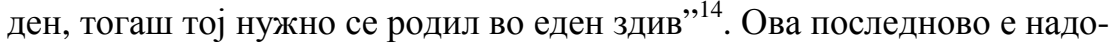
полнето со комуникацискиот модел на Роман Јакобсон, кој започнува од испраќачот, кој е извор на пораката што се пренесува. Но од каде доаѓ тој испраќач? За да биде способен да испрати порака, тој или таa, веќе мора да биде „фатен” во јазикот или конституиран од него ${ }^{15}$.

\section{Мод(а)ови, време е за Фолтин}

Би сакале она што веќе подолго време тлее тука околу нас, да се вообличи во еден образец за поезијата на Фолтин, за тековното да не е замолчено. Всушност станува збор за модовите време согледани

\footnotetext{
${ }^{13}$ Н. Шкрињариќ, Митски координати, Скопје 2008, стр. 163.

${ }^{14}$ Т. Иглтон, ор. cit., стр. 41.

${ }^{15}$ Ibidem.
} 
преку есејот Слободата на убавото од Џулиус Т. Фрејзер ${ }^{16}$, времето како предизвик и пловидбата со бродот наречен Фолтин. Расчленувањето на модовите темпоралности од наша страна, нема за цел да дава одговори на прашањето што е време.

Главните ознаки на различните светови (човекот и неговиот универзум), промислувани како иднини на природата и општествата во кои би сакале да живееме, покажуваат различни поставености на чувствата. Овие афективни димензии на темпоралните светови, Фрејзер ги опишува како нивни модови. Слободата е овозможена со способноста на свесното искуство, неограничено да снова меѓу видовите темпоралност (модови), а потем да се враќа и говори за своето патешествие. Така Фрејзер ја опишува слободата на убавото. Понатаму, Фрејзер разликува повеќе состојби на чувство за безвременост, некои ги нарекува: екстаза на шумата, екстаза на танцот, екстаза на будоарот ${ }^{17}$ (фp. boudoir - 'мал, елегантвно украсен женски салон' $)^{18}$. Во овие и многу други постоечки екстази чувството на безвременост не претставува целосно отсуство на времето (што, на пример, би следело по губењето на свеста), ниту, пак, овие состојби на умот треба да се мешаат со условите на атемпорален хаос (случај на болна збрка на некои шизофренични напади).

Прототемпорални. Во прототемпоралноста временските и просторните положби на настаните не се добро одредени, а настаните и стварите понекогаш можат да се заменат, следствијата се веро-

${ }^{16}$ Џ.Т. Фрејзер, Слободата на убавото, во: Човекот и времето, приред. Д. Јакимовски, Скопје 1990, стр. 211-239.

${ }^{17}$ На пример, вниманието може да биде ограничено врз една неменлива точка или процес. На тој начин се истакнува постојното од егзистенцијалноста, а се задушува менувачкото; нерешливиот конфликт на осамостојувањето ослабува и светот на умот почнува да наликува на еотемпоралното. Изчезнува насоката на времето; се губат определбите на сегашноста и сопството. Таа е состојба на занес може да се нарече екстаза на шумата. Вниманието може да се насочи и врз постојана промена, преку екстазата на танцот. Светот на умот е повторно еотемпорален. Сексуалниот однос ја нуди во еден непромислен чин безвременоста на танцот, следена со екстазата на шумата, во една екстаза на будоарот. Еотемпоралниот свет кој често ја опишува состојбата на умот после сексуален однос, лесно се втопува во она смалено ниво на будност - гаранција на сонот.

${ }^{18}$ Cf. Џ.Т. Фрејзер, op. cit., стр. 211-212. 
јатностни ${ }^{19}$. На пример, дадаизмот - протест што не е насочен кон кој и да е посебен метод на организација, туку кон самата организираност; сликите на Џексон Полок и сл. Во нашиот случај ќе направиме обид да го илустрираме овој мод, преку пример од репертоарот на Фолтин. Впрочем, тоа најдобро се согледува во песната Топка:

$$
\begin{aligned}
& \text { пи́-па-ла́-па-т-п-та́ } \\
& \text { о-о́-к-т-по-то́д-по-то́д-по-то́д }
\end{aligned}
$$

Инспирација за песната е синтагмата: пипалата на октоподот, и како што вели Бранко: „во песнава мора да се стават акценти, само со нив се постигнува конкретениот ритам”. Пронаоѓачот (авторот) е измислувач и градител на постројките (се мисли на избраните фонемите) во производствен ритам, т.е конструктор на една ритмички повторуваана структура, што е звучна и ритмичка градба на песната (акцентирање на ритамот и звукот што се произведува при топкање со топка). Истиот тој е и изместувач на плански граденото значење (пипалата на октоподот) и подметнувач за разбивање на значењето, т.е. деконструктор на значењето. Така песната е ослободена од значењето и планската организација, што не значи отсуство на целосно значење, бидејќи има звучна градба и создадена ритмичка целина, што ứ дава на песната ослободена естетска вредност. Имено, градбата на песната е непредвидлива, фонемите се намерно пуштени во игра, броиви, произволно споени еден со друг, стиснати или раширени, скратени или додадени. Тие ја изразуваат прототемпоралната неискажливост која произлегува од „молитвените” извори на чувствата. Односно првобитната опчинетост на човекот со играта и танцот. Се чини дека прототемпоралните модови комуницираат со архаичните нивоа на нашиот ум.

\section{Еотемпорални.}

Погледнете - пишива Џулиус Фрејзер - кој и да е од мноштвото рани египетски релјефи, во кои секој дел од телото е претставен во својата најречита перспектива. Рамењата се видени однапред исто како и очите; но лицето и рацете се во профил. Обично се вели дека уметникот користел различни перспективи; го замолил моделот да се сврти или го замислил

\footnotetext{
${ }^{19}$ Cf. ibidem, стр. 13.
} 
движењето. (..) Уметникот го собрал она што го видел во различни времиња. Доминантниот мод на таковите релјефи е еотемпорален ${ }^{20}$.

Прославената слика на Пикасо, Госпоѓиците од Авињон, е чисто еотемпорална во својот доминантен мод; потсеќ на старите египетски релјефи. Насушно, кубизмот инсистира врз еотемпоралниот мод. Со еотемпоралниот мод Бранко прескокнува децении, различни фази од животот на Рацин и Конески. Односно, двата лика-прилика (една за друга), Ленка и Везилка, во песната на Фолтин се поставени во една тајновидна привлечност. Кохерентната поетска целина ги сочинува како да биле истовремени. Поетот не нашол ништо несоодветно во здружувањето на ,животите” од различни времиња, во една неизделива сегашност. Во песната за Везилка и Ленка на Фолтин нема ништо неконзистентно, доколку му дозволиме на поетот временски да го сецира онавековието, и да здружува повеќе видувања од различни времиња во еден поглед. Впрочем, митот, како и јазикот, е „машина за запирање на времето". Токму образувањето на песната на Бранко Николов е создавање, односно раѓање, сотворение по Рацин и Конески. Таа вистина ги интегрира нашите лични чувства во поширок комплет на претпоставки, за начинот на којшто општеството би требало да функционира. Значи, структуралната врска Везилка - Ленка, како спој за трансмисија на пораки, не е ли митема (најмала структура во митот за нашето нешто?)? Таа е свет на чиста поезија, „проста и строга песна", синхрон пристап во универзалниот мит, во кој сегашноста се испреплетува со минатото и ја предвестува иднината. Се вели мит, затоа што митот не го примаме како лага, туку како лоза, како градивно ткиво за секој идентитет.

Увертирата во песната Везилка е опис на екстазата на будоарот. Внимателниот исчитувач ќе насети и ќе открие машки и женски оргазми од преживеаното, текстуално видоизменети. Прекрасната истоштеност од вчерашниот ден ги следи нив во утрото, со глад за повторно утринско „едначење”, но потоа се крева завесата и го отвора прашањето кон Везилката („Везилке, Везилке, кажи како да се роди проста и строга македонска песна?”), откривајќ ги голи Младиот и Младата во креветот на будоарот. Прашањето што е упатено кон

\footnotetext{
${ }^{20}$ Ibidem, стр. 216.
} 
Везилката има за цел да искаже правец на движење, нешто како денешна цел (песна или сл.), но нема намера да го опфати и неговото достигнување. (За да биде појасно кее дадеме еден пример: Патот кон селото води низ шумата. Тој води низ шумата, но ние не сакаме да одиме во селото, бидејќи тука ни е убаво). Впрочем, го изразува само стрмежот кон нешто недовршено (,...откако Ленка остави...”). Во продолжение авторот како да сака да го раскаже резултатот од претходното дејствие. Токму затоа, разголената интима на обајцата од нејзината префина женска соба, ја излива врз публиката преку музиката. Музиката во песната е како наддавање, разоткривање на текстот. Втората строфа од песната Везилка е несомнено музичка слика на екстазата на танцот. Единство на непопустливост на една текстуално и ритмички повторувана форма; експлозија на танцот. Џулиус Фрејзер тоа го нарекува екстаза на танцот ${ }^{21}$. Школски пример за екстазата на танцот е делото Болеро на Морис Равел, коешто е хипнотичко крешчендо, или, пак, Крафтверк, коишто се сјајно оркестриран тур-де-франс.

Песната Во јули Битола 22 од Фолтин ја носи екстазата на шумата. Нејзината мелодија е заситена со атмосфера на севезден (нон стоп) мрзливо време. Секојдневието е неменлив процес во јули во Битола. Траењето на времето е поим кој објаснува како поетот во песната може да повторува епизоди и да ,паузира” (,„љуби ме, вдиши ме, луби ме, вдиши ме, задржи здив”). Фразата „на керамиди се лепат жештини" е метафора на тивката контемплација на бескрајноста на „облаците и небото”, чии протегања се во далечината на морето. Времето и неговата тајна во јули во Битола се мит за неминливоста на времето во Битола. Неминливоста на времето ја нарековме мит, а не илузија, затоа што во неа не е вклучена измама на чувствата. Го употребуваме митот затоа што оваа претстава за времето во Битола е избор на личниот јазик, како и на јазикот на литературата, преку кој се обидуваме да го израземи искуството во јули во Битола. Овој мит врши големо влијание врз нашата виртуелност и еотемпоралност.

${ }^{21}$ Cf. ibidem, стр. 212.

22 За текстот на песната и за повеќе информации види: <www.facebook. com/foltin.band?sk=info> [преземено: 23.01.2012]; 〈www.myspace.com/foltin> [преземено: 27.01.2012]; <www.youtube.com/jovanoski> [преземено: 27.01.2012]. 
Времето во јули во целост ги опфаќа сите витални институции (ментални и физички) во градот и е еден од неговите неопходни чинители. Ништо не може да се стори без да се прифати времето како коавтор. Времето во јули во Битола не може да се раздели од економски, политички и идеолошки потреси. Таквото време ја чува уметноста од политиката и заборавот. Во исчитувањето на поетската идеја треба да се укаже и за јасноста, дека не се мисли само на хоризонтален пресек на времето - жега, туку присутна е и вертикалната оска „облаците и небото се море немирно”. Впрочем, „задржи здив” до следниот јули. Чинам овој задржан здив ќе го оддели творештвото од трулото, сувото од сурово.

\section{Проста и строга митска игра}

Синтагмата проста и строга (песна) од Везилка на Конески е анализирана од многу автори, во бројни текстови. Би се задржале само на неговите современици. И во духот на тој дискурс ќе забележиме свои коментари. Ј. Бошковски прв го воочува значењето на таа синтагма, сметајќи ја за систем на бинарен исказ, во кој двата збора, иако не се опоненти, кажуваат две сосема различни содржини. Бинарниот исказ, според Бошковски, се поврзува со вториот, силен бинарен синтагматски спој црно/црвено. Уверувањето дека тие две синтагми проста/строга - црна/црвена се наоѓаaт во врска како прашање - одговор, произлегува од формата и текот на песната. Па можат да се сочинат вакви двојки, во смисла на принципот: прост/црн, строг/црвен, или обратно, зашто песната дава и таква можност ${ }^{23}$.

Се чини дека определувањето на Конески е да го искаже низ црн и црвен, низ тие два созвучни збора, единството на егзистенцијата, нејзината хармонија наспроти сѐ, но не и спротивностите. Така, можеме да заклучиме и за бинарниот изказ проста и строга, дека одредниците не му се контрастни туку комплементарни ${ }^{24}$. Всушност, ортодоксните структуралисти не би ги интересирало контраст/ комплементарност, туку самата структура, што ја гради аналогната врска

${ }^{23}$ Cf. С. Мицковиќ, op. cit., стр. 104-106.

${ }^{24} \mathrm{Cf}$. ibidem. 
помеѓу нив, но тоа ќе го објасниме понатаму со наше мислење и примерот за Фолтин.

Р. Ивановивиќ ја разчленува поетската порака проста/совршена, строга/трајна. Со овој пресек не се унапредило сознанието за значењето на синтагмата. М. Ѓурчинов забележува дека проста = едноставност на поетскиот израз, строга = строгост во градењето на песната. Едното како и другото говорат за експресијата на песната. В. Урошевиќ во контрастната синтагма црн/црвен ја идентификува вечната спротивставеност меѓу љубовта и смртта, светлината и мракот, космосот и хаосот. Р. Ивановиќ го едначи со опозицијата смрт/ живот ${ }^{25}$.

Во ваквите и слични толкувања на синтагмата ,проста и строга македонска песна”, насетуваме митски координати. Впрочем, ја оставив мислата на поетот да тече кон „македонска песна”, сѐ со една цел. Имено, Конески коментира вака:

Во која смисла „нашите” го употребувате? Митот е форма на општочовечко искажување (...) Мене страшно ме нервира израз „македонска куќа”. Ме нервира израз „македонска бавча”, затоа што такво нешто нема во историска смисла. А има моја куќа, има моја бавча... ${ }^{26}$.

Според А. Вангелов тој критериум - простата и строга песна, се рашири потоа на целокупната поезија на Блаже Конески, постигнувајќи степен на општа и непосредна одредба. За Слободан Мицковиќ токму синтагмата проста и строга е израз на согласни (созвучни) зборови, односно како епитети кои се надоврзуваат, а не се контрираaт $^{27}$. Тие на специфичен начин укажуваат на сосема јасно одреден квалификатив - проsирност. Стремежот кон ваквиот израз го искажува и Елиот кога вели дека сака да пишува: „поезија што стои гола во своите коски, или поезија што е толку провирна што не треба да ја видиме поезијата, туку да гледаме низ поезијата, поезија толку провирна, што кога ја читаме нашето внимание го сосредоточува врз она што поезијата го изкажува" 28 .

\footnotetext{
${ }^{25}$ Cf. ibidem.

${ }^{26}$ Ц. Андреевски, ор. cit., стр. 299.

${ }^{27}$ Cf. С. Мицковиќ, ор. сit., стр. 106.

${ }^{28}$ Ibidem, стр. 107.
} 
Блаже Конески, пак, на прашањето да го коментира истиот стих од Везилка, ќе рече: „Тоа е барање песна што треба да соопшти нешто важно и сериозно, а освен тоа да биде доведена до својот проsирен израз" ${ }^{29}$. Точно е дека прозирноста на песната ја подразбира едноставноста, но под услов песната да кажува нешто важно и сериозно.

Срцеликата стамена, јасна и едноставна песна на Фолтин, ,ја сруши старата камена ограда" на Везилка и Ленка. Сепак треба да се каже дека овие размислувања не се целта на овој текст, туку да појаснат како Фолтин ги обликуваат двата листа (двете песни) во „главата" на народот, како една целина, т.е. едначене по значење. Треба да се каже и тоа дека народот сам си го бара тој континуитет, тоа единство, таа лубов да сврзе два автори, коишто се пресудни во нашата литература; имаат цел да ги спојат двата конци (црвен и црн на бела основа) во едно цело/идентитет и да ги реактуелизираат самите автори и нивното творештво.

И повторно да се навратиме на Разговорите...:

- Андреевски: Добро, а за песната?

- Конески: Песната нема граница (...) Јас не сум за тоа специјалист, ама толку знам дека сето тоа нема граници, во кои ние во некакви учебници национални сакаме да ги поставиме (...) Што се однесува до митот, тој е уште поопшт ${ }^{30}$.

\section{Пренос на пораки}

Според Леви-Строс митот не е напросто сказна, туку носи порака. Иако не е секогаш јасно кој ја испраќа таа порака, извесно е кој ја прима, поточно се работи за воведувањето на новите членови на заедницата, кои слушајќи ги митовите, ги примаат основните претпоставки на сопствената традиција, која на некој начин се пренесува од секогаш и севезден, следејќи го принципот на континуитет. На тој начин митот врши функција на социјализација ${ }^{31}$. Конески во воведниот текст Mojom onum, кон изборот од својата поезија Стари и нови песни, изнесува суштински согледувања со митска универзал-

\footnotetext{
${ }^{29}$ Ibidem.

${ }^{30}$ Ц. Андреевски, ор. cit., стр. 302.

${ }^{31}$ Cf. Н. Шкрињариќ, op. cit., стр. 158.
} 
ност. Тука се изделуваат неколку битни прашања. Конески воспоставува еден јасен однос во триаголно поставени елементи: автор традиција - колектив. Тоа е тричлена релација од поопштиот космос: Антропос - космос - логос. Тој троен однос кај Конески беше извонредно сериозно и студиозно сфатен кај сите негови толкувачи потоа ${ }^{32}$.

Кај „Фолтин” ова може да се претпостави, со тоа што до израз ќе дојде континуитетот. Токму ова може и вака да се постави: автор (Фолтин) - традиција (Конески, Рацин) - заедница. Тука функцијата на медијатор, како прогресивно и градежно посредништво, ја има Фолтин, сочинувајќи два лика, од две песни, од два наши најпознати поети. Во Фолтин блика, вирее делотворна сила. Таквата музика има снага, количина на моќ, но не како идеја, туку sуни со својата стварност (тага и радост). Помирување на нужното со слободното. Тоа е она што е најфиното и најчистото во нешто. Поетската структурална врска, навидум произволна, преку музиката на Фолтин е вистинска средба со личностите кои се сведоци на нашето постоење. Музичката содржина истовремено е вртоглава и спокојна (нежна) неизвесност, чиста емоционална иднина, авторска сила, за во неизматен и чист етер. Згора на тоа, збир на она што е најубаво во нешто, срцевина, суштина. Целта на приказните е да го инволвираат раскажувачот и публиката, а целта на митовите, што се производ на приказните со висока вербална уметност, им е да го интегрираат раскажувачот и публиката. Содржината на митовите обично се однесува на минати настани (на почетокот на времето) и идни настани (обично на крајот од времето). Фолтин се општествено „митски”, бидејќи овие структурални врски, со сета своја долга и важна минатост, ги надвезуваат на изразите на лицата на луѓето со целисходна опчинетост.

\section{Заруменето срце}

Магијата во песната дадена подолу е во начинот на кој таа опишува еден процес. Сѐ е јасно и ништо не е јасно, прекрасен трик „налик на вадење зајак од капа”з3. Имено, треба да се има „волја за

\footnotetext{
${ }^{32}$ Cf. С. Мицковиќ, op. сit., стр. 10.

${ }^{33}$ И. Џепаровски, Одате системот, Скопје 2000, стр. 288.
} 
мисла”, за да се прими мислата-лисица во себе. Трагите од „швалерскио воз" се пресоздаваат во заплет на празниот лист од хартијата. Возот е персонификација на поминувањето, носеќи ги спомените. Нема никаков сомнеж дека станува збор за песна од која еманира самата песна. Песна која ги разоткрива обајцата, со сета своја суптилност, моменти на инспирација и процес на имагинација, без кои нема поезија.

87

Мојот ефтин итоф

И твојте чудесни чорапчиња

Плетат заплет тежок замрсен

Деновиве ке минам

Низ твојот весел град

Ти порано ке легнеш

A јас ќе задоинам

Почекај запали испуши до крај

Швалерскио воз е во два

Tu-mu-mu-Ta

mu-mu-mu-Ta-ma-ma

Швалерскио воз е во два

Од наша перспектива поезијата на Фолтин успешно плови на „три води”. Со можност за присуство, па отсуство од приказната, за крај, можност за она јас кое раскажува (,,...мојот ефтин штоф и твојте чудесни чорапчиња...”). Токму оваа слобода во исразот е препознатливо „фолтинска”, без умор за изненадување, и со форма на препознавање. Во извесна смисла, она јас кое го опишува е идентично со она јас кое раскажува, но во друга смисла се воздржува од него (,... почекај... швалерскио воз е во два") - со конструкција што е пауза, за повторно да ја изгради улогата јас (,,...ти порано ќе легнеш, а јас ќе задоцнам...”). Чинам, сонот за полифонија во поезијата е исполнет.

Ова трансплантирана / Машина за чукање / Досега не типкала / Љубо́вно писмо $/ x 2$

Чукам по старите/ Возбудени дирки / Приближно 90 / Удари во минута

Чукам по старото / Механичко срие / Пулс, Масажа / Адреналин 
Повод за љубовно писмо е некаква игра. Причината е играта на срцето, која не се искажува лесно со постојните знаци на јазикот. Тоа бара друг код за распознавање, за комуникација. Поетот се обидел повишено емотивно да ứ пристапи на оваа сложена поетска идеја, преку звук и знак, во взаемна поврзаност. Песната Ова трансплантирана машина за чукање досега не типкала љубовно писмо е нарација, опис, чувство за себеси, загатнување за разговори на сериозни теми, разводнување на темите (како последица на логична замореност) и сведување на три логични збора пулс, масажа и адреналин, што „враќаат облаци” на „земјата” (во душата). Потоа разидување. Но, и задоволство од поминатиот „напад” што понудил благороден стимул на денот.

Румени се руменат образите / Румени се руменат образите

Но, зошто да порасне љубо́вта наша / Ако ја разебиме, ќ заебиме

Овој сладок дремеж на жешкото соние / Кंе се стопи нежно ко сладолед

Румени се руменат образите / Од љубовта треба да се пазиме / Од љу-

бовта треба да се пазиме

Песна со рефренски резонанс. Чинам не се насетува измореноста од убавината, ниту, пак, тоа би било особено важно. Доживувањето на убавината сама од себе предизвикува возбуда. Возбудата, пак, се разбира е немир. Отука би произлегло дека станува збор за потрага по спокој - „Овој сладок дремеж на летното сонце ќе се стопи нежно ко сладолед”. Руменилото како да сака да се подзаскрива зад сонот, очигледно нешто им се случило. „Ах, румени се руменат, образите. Од љубовта треба да се пазиме". Јазикот во музиката на Фолтин не секогаш служи да ја опише реалноста: понекогаш тој е перформативен, односно насочен кон извршувањето на некоја акција. Дури и фактичкото руменило, или констативниот јазик (,...од љубовта треба да се пазиме...”) се чинови на известување и потврдување, а пренесувањето на информацијата е исто толку изведба (performance), колку давањето име на брод, наречен Фолтин. Тие во најдраматична форма ни го враќаат тоа чувство за лингвистичка изведба. Нивната музика успева да постигне нешто во самиот чин на искажувањето: таа е јазик како некој вид материјална пракса, дискурс кој општествено делува. 


\section{Бранко, Јуриј Лотман и Фреј}

Делото на Нортроп Фреј, во книгата Анатомија на критиката (1957 г.), може да се опише како структуралистичко. Познато е дека тоа дело е современик на растежот на класичниот структурализам во Европа. Структурализмот, како што кажува и самиот термин, се занимава со структури, и особено со испитувањето на генералните законитости според кои функционираат. Структурализмот ги сведува поединечните појави на голи примери за таквите закони. Но во ортодоксниот структурализам има една доктрина која недостига кај Фреј: убедувањето дека поединечните составки на еден систем стекнуваат значење само преку односите што ги воспоставуваат меѓу себе. Ова не произлегува од едноставното убедување дека би требало нештото да го набљудуваме структурално. Можеме една песна да ја разгледаме како структура, а сѐ уште да го третираме секој нејзин елемент како нешто што повеќе или помалку има значење само по себе ${ }^{34}$.

\section{Lo-Lee-Ta-Too}

Jumpy, sweaty fingers

That's the Beast.

His tongue, 6 inches long

Makes 300 taps per minute.

His favorite finger

Also makes 300 tpm-s

And is 5.3 inches long.

Sometimes

He wears a ring,

Benny Good-one,

Quite expensive,

But, the new Clarinette-

She's a real Bitch!

So, it seems that when I play

I make love to my little Clarinette

And she's probably screamin'!

\footnotetext{
${ }^{34}$ Cf. Т. Иглтон, op. cit., стр. 14.
} 
Ladies ' $n$ Gents of the Jury

Mr. Woody Allen is shootin' a movie

Is it the Beauty and the Beast

Or the Beast and the Beauty!

Гледаме дека песната содржи една слика на Убавицата (Clarinette) и една слика на Sверот. Нас нѐ интересира на кој начин овие две слики се усогласуваат за да оформат структура. Но, ние стануваме структуралисти „со тапија”, само тогаш кога тврдиме дека значењето на секоја од тие слики е целосен резултат на односот што тие го воспоставуваат. Во тој случај, сликите немаат супстанцијално, туку само релационо значење. Според оваа доктрина не мора да „излеземе” од песната и да го консултираме знаењето за тоа што е убавица, а што sвep, за да ги објасниме сликите; тие меѓусебно се објаснуваат и се дефинираат. Во песната Lo-le-Ta-Too, Beast и Beaty меѓусебно ја објаснуваат структурално-поетската мисла на поетот. Нашата рецепција на граматичката структура на песнава може да го направи читателот многу поотворен за нејзиното значењето. Токму тогаш, кога еден систем во песната се заканува да стане премногу предвидлив, некој друг систем ќе го „пресече”, ќе го наруши и ќе го исфрли во нов план. Ако два збора си асоцираат еден на друг, поради сличната звуковна градба, или поради сличната позиција во метричката шема (тука спаѓа и посебното акцентирање на слоговите во пеењето), тогаш тоа ќе предизвика поостра перцепција на нивната значенска сличност или различност.

Литературното дело на Бранко Николов (Фолтин) постојано го збогатува и го менува чистото речничко значење на зборовите, создавајќи нови значења преку судирот и кондензацијата на сопствените разновидни рамништа. Бидејќи секои два збора можат да се јукстапонираат врз основа на некое својство на еквиваленција, следствено таквата можност е горе-долу неограничена. Еден збор во текстот е сврзан со неколку други зборови преку цел систем на формални структури, така што неговото значање е резултат на неколку различни одредници кои делуваат заедно. Еден поединечен збор може да се сврзе со друг преку асонанца (призвук), со трет преку синтактичка еквиваленција, со четврт преку морфолошки паралелизам и слично. 
Така секој знак симултано учествува во неколку различни парадигматски модели или системи. Поетскиот текст, според Јуриј Лотман, е систем од системи, релација на релациите. Тоа е најсложената форма на говор што може да се замисли, затоа што кондензира повеќе системи, од кои секој содржи свои лични тензии, паралелизми, повторувања и опозиции, така што секој од нив постојано ги модифицира сите други. Песната, всушност, може да биде само препрочитана, а не прочитана, поради фактот што некои нејзини структури можат да бидат перцепирани при повторното читање. Поезијата го принудува зборот, под притисок на околните зборови, да го даде својот максимум, па на тој начин да го ослободи својот најбогат потенцијал ${ }^{35}$.

\section{Гарнета}

\section{Врвот на јазикот минува пат}

Пат од три степени по непцето ќе мине

Врвот на јазикот минува пат

И на крај во забите ќе лупне:

Гар-не-та, Гар-не-та-ту!

I want to show

There's so many things about...

Лена, Милена, цанам, Лилјана

I want to show

There's so many things about...

The tip of the tongue

Is taking a trip

Of three steps down

The palate to tap

At three

On the teeth-

Tasting the name

With the tip of the tongue

Грнета е еден вид музички народен инструмент - кларинет. Но во оваа песна, како и во lo-lee-ta-too (Clarinette), очевидно е дека не станува збор само за кларинет - музички инструмент; всушност и во

\footnotetext{
${ }^{35}$ Cf. ibidem, стр. 26.
} 
двете песни се работи за лични имиња. Она што во оваа песна е фасцинантно е едноставноста и јасноста, на скоро физичкото присуство на грнетата во песната. Нејзиното притаено движење во усната шуплина, јазикот што минува пат, кој токму во тој момент сега, и пак сега, еве сега и сега, го испушта своето движење во ритам што замелушува. Згора на тоа, од насловот доволно е јасно и очигледно дека станува збор за Гарнета - девојка, што едновремено е и гарнета (девојка) - мисла. Како мислата да се префрлува од стварноста на „дрвената природа” на кларинетот, во стварноста на човековата имагинација и креација. Префрлањето е тивко, спокојно, ненаметливо, слеано со самотијата на нараторот на песната, кое ја отвора „црната дупка на својата глава" за во неа да влезе мислата.

За последно, како што кажавме повеќе пати, Везилка и Ленка во песната 120 сами си се пресоздаваат во структурален сооднос и нема потреба веќе од наша интервенција: (тркалото го свртија Фолтин), а неспорно е и дека двете песни и двата лика си имаат преголемо значење сами по себе. Важно е овде дека дури и отсуството на извесни постапки во поезијата може да произведе значење. Ако кодовите што ги воспоставило делото нѐ наведуваат да очекуваме рима или хепиенд, а тие не се реализираат, оваа минус постапка, како што jа именува самиот Лотман, може да биде подеднакво ефективна единица на значењето колку и секоја друга. Имено, ќе дадам еден пример од песната на Блаже Конески, Везилка, и песната на Фолтин, 120 . Конески прашува:

Везилке, кажи како да се роди / проста и строга македонска песна од ова срие што со себе води, / разговор нокен во тревога бесна?

Бранко (Фолтин), минус постапката ја прави со накалемување:

Везилке, Везилке, кажи како да се роди, / Проста и строга македонска песна?

Откако Ленка остави кошула тенка / Ленена недовезена на разбој...

Поезијата на Фолтин е постојано производство и изневера на очекуваното. Комплексна меѓуигра на регуларното и случајното, на нормата и отстапката, рутинираните шаблони и драматичните очудувања. Новиот музички албум што тие го подготвуваат и исполнетоста 
на нивната музика со поезија, како нешто нераскинливо во нивниот свет на игра (живот-музика-поезија), отвора нови врати за иследување на оваа разработка. За крај, овој текст има за цел да ја разбудува науката, можноста да се тргнат маргините од форматите на научни дисциплини и да се пристапи кон интердисциплинарно „искористување” и „музицирање” со различни инструменти. И уште повеќе, да може на маса да се стават игри со отскокнување од дисциплинарноста; тогаш интересите на истражувачите ќе се рашират, а квлитетот во науката ќе порасне.

\section{Литература}

\section{Кирилица}

Андреевски Ц., Разговори со Конески, Скопје 1991.

Иглтон Т., Структурализмот и семиотиката, во: Судбината на значењето, приред. В. Андоновски, Скопје 2007, стр. 9-60.

Конески Б., За Кочо Рацин, Скопје 1994.

Мелетински Е.М., Поетиката на митот, Скопје 2002.

Мицковиќ С., Поетските идеи на Конески, Скопје 1986.

Фрејзер Џ.Т., Слободата на убавото, во: Човекот и времето, приред. Д. Јакимовски, Скопје 1990, стр. 211-239.

Џепароски И., Отаде Системот, Скопје 2000.

Шкрињариќ Н., Митски кординати, Скопје 2008.

\section{Латиница}

Levi-Stros K., Mit i značenje, prev. Z. Minderović, Beograd 2009.

\section{Интернет страници}

<www.facebook.com/foltin.band?sk=info> [преземено: 23.01.2012].

<www.myspace.com/foltin> [преземено: 27.01.2012].

<www.youtube.com/jovanoski> [преземено: 27.01.2012]. 
